\title{
PENGARUH KADAR TRIPTOPAN PAKAN TERHADAP PERTUMBUHAN DAN SINTASAN KRABLET KEPITING BAKAU, Scylla serrata SELAMA MASA PENDEDERAN
}

\author{
Usman\#, Kamaruddin, dan Asda Laining \\ Balai Penelitian dan Pengembangan Budidaya Air Payau
}

\begin{abstract}
ABSTRAK
Kepiting bakau bersifat kanibal dan cenderung memiliki laju pertumbuhan yang lambat ketika diberi pakan buatan. Triptopan adalah salah satu asam amino esensial untuk pertumbuhan dan merupakan prekursor pembentukan serotonin yang dapat mengontrol sifat agresif pada beberapa vertebrata. Penelitian ini bertujuan untuk mendapatkan dosis optimum triptopan pakan terhadap pertumbuhan dan sintasan krablet selama masa pendederan. Empat dosis penambahan L-triptopan dalam pakan yaitu: $0 \%(\mathrm{~A}) ; 0,25 \%(\mathrm{~B}) ; 0,5 \%$ (C); dan $1,0 \%(\mathrm{D})$ dengan kadar triptopan dalam pakan berturut-turut $0,41 \% 0,52 \%, 0,67 \%$ dan $0,96 \%$ serta kontrol berupa pakan rebon kering (E) yang mengandung triptopan sebanyak 0,79\% Hewan uji yang digunakan adalah krablet kepiting bakau berumur 3-5 hari sejak memasuki stadia krablet. Krablet dipelihara dalam bak fiber berukuran $1,0 \mathrm{~m} \times 1,0 \mathrm{~m} \times 0,5 \mathrm{~m}$ sebanyak 15 unit dengan kepadatan masing-masing 50 ekor $/ \mathrm{m}^{2}$. Selama lima minggu pemeliharaan, krablet diberi pakan uji sebanyak $30 \% 15 \%$ hari. Hasil penelitian menunjukkan bahwa krablet yang diberi pakan mengandung triptopan $0,67 \%$ menunjukkan laju pertumbuhan tertinggi dan berbeda nyata $(P<0,05)$ dengan krablet yang diberi pakan mengandung triptopan $0,41 \%$ Rasio efisiensi protein tertinggi juga didapatkan pada krablet yang diberi pakan mengandung triptopan $0,67 \%$ dan berbeda nyata $(P<0,05)$ dengan krablet yang diberi pakan rebon. Sintasan, konsumsi pakan harian, rasio konversi pakan, dan komposisi proksimat total tubuh krablet relatif sama di antara perlakuan, meskipun ada kecenderungan terbaik pada krablet yang diberi pakan mengandung $0,67 \%$ triptopan.
\end{abstract}

\section{KATA KUNCl: $\quad$ krablet; pertumbuhan; sintasan; pakan buatan; triptopan}

ABSTRACT: Influence of dietary tryptophan levels on growth and survival rate of mud crab, Scylla serrata, during nursery. By: Usman, Kamaruddin, and Asda Laining

\begin{abstract}
The main constrain in mud crab culture is high cannibalism which are triggered by several factors such as limited space, lack of feed and large size variation. Mud crab also has relative slow growth when fed artificial diet. Tryptophan is an essential amino acid for growth and precursor of serotonin which can control natural aggressiveness in vertebrates. This study was conducted to obtain optimum level of tryptophan in diet for mud crab during nursery. Four test diets were formulated to contain different levels of supplemental L-tryptophan at: $0 \% 0.25 \% 0.5 \% 1.0 \%$ and as the control diet was dried mysid, so the tryptophan levels of the test diets were $0.41 \%(A), 0.52 \%(B), 0.67 \%(C), 0.96 \%(D)$, and $0.79 \%$ (mysid, E) respectively. Crablets (3-5 days post-methamorphosis) with average initial weight of $0.039 \mathrm{~g}$ were randomly distributed into 15 of $1.0 \mathrm{~m} \times 1.0 \mathrm{~m} \times 0.5 \mathrm{~m}$ fibre glass tank with density of 50 ind./tank. The crablets were fed daily the test diets at $30 \%$ to $15 \%$ of biomass. After five weeks feeding trial, crablet fed the diet containing $0.67 \%$ of tryptophan had significantly $(P<0.05)$ higher weight gain compared to crablet fed diet containing $0.41 \%$ of tryptophan. Highest protein efficiency ratio was also obtained in crablet fed the diet containing $0.67 \%$ of tryptophan and significantly different $(P<0.05)$ with crablet fed dried mysid (control). Final carapace width, feed conversion ratio, and survival rate were not significantly different $(P>0.05)$ among the treatments.
\end{abstract}

\section{KEYWORDS: crablets; growth; survival rate; artificial die; tryptophan}

\section{PENDAHULUAN}

Kepiting bakau merupakan salah satu komoditas potensial untuk dibudidaya secara komersil di kawasan

\footnotetext{
\# Korespondensi: Balai Penelitian dan Pengembangan Budidaya Air Payau. J. Makmur Dg. Sitakka No. 129, Maros 90512, Sulawesi Selatan, Indonesia. Tel.: + (0411) 371544 E-mail: siganus007@ yahoo.com
}

Asia Pasific (Keenan \& Backshaw, 1999; Trino \& Rodriguez, 2002). Di Indonesia, kepiting bakau menjadi komoditas ekspor dari sektor perikanan yang memiliki harga jual cukup tinggi (> Rp 75.000,00/kg) di tingkat petani. Produksi kepiting bakau di Indonesia masih didominasi oleh hasil tangkapan di alam karena kegiatan budidayanya belum berkembang 
seperti komoditas udang windu, vaname, ikan bandeng, dan beberapa jenis ikan budidaya lainnya. Hal ini disebabkan oleh beberapa faktor seperti ketersediaan benih yang masih mengandalkan hasil tangkapan di alam, ketergantungan penggunaan pakan ikan rucah yang kualitas dan kontinuitasnya fluktuatif, dan tingkat kanibalisme kepiting yang tinggi. Oleh karena itu, kegiatan pembenihan kepiting bakau harus terus diupayakan untuk memenuhi kebutuhan benih kepiting bakau bagi pembesarannya di tambak.

Pada kegiatan pembenihan kepiting bakau di Balai Penelitian dan Pengembangan Budidaya Air Payau, Maros telah dapat dihasilkan krablet kepiting bakau namun jumlahnya masih sangat terbatas $<10.000$ ekor/tahun). Salah satu penyebabnya adalah tingginya tingkat kanibalisme (sintasan yang rendah, rata-rata $<60 \%$, dari saat memasuki stadia krablet-1 hingga ukuran yang siap tebar di tambak pembesaran (lebar karapas $\geq 1,5 \mathrm{~cm}$ ) (Gunarto, 2012). Sifat kanibal kepiting bakau mulai muncul pada stadia megalopa karena saat itu sudah memiliki capit, dan tertinggi terjadi pada saat stadia krablet selama masa pendederan dengan kepadatan yang relatif tinggi (Ut et al., 2007). Beberapa upaya yang telah dilakukan untuk menekan tingkat kanibalisme pada pendederan krablet kepiting bakau ini antara lain penggunaan shelter (Cerezo, 2001; Gunarto, 2012), pengaturan kepadatan, dan jenis pakan (Ut et al., 2007).

Sifat kanibal dipicu oleh adanya perbedaan ukuran yang mencolok di antara individu, serta ketidakcukupan pakan baik kuantitas maupun kualitas dalam suatu wadah atau badan air yang terbatas (Folkvord \& Ottera, 1993; Hecht \& Piennar, 1993; Folkvord, 1997). Namun demikian, secara biologis faktor kanibalisme ini timbul oleh adanya naluri sifat dominan dari suatu individu terhadap individu lain yang diakibatkan oleh perbedaan kemampuan mendapatkan makanan dan Iaju pertumbuhan, meskipun makanan diberikan secara ad libitum (Hseu et al., 2003). Menurut Wilson (1975), sifat kanibal merupakan suatu tindakan penyerangan predator secara intraspesifik. Pada banyak hewan vertebrata, peningkatan aktivitas serotonergik otak menyebabkan penghambatan terhadap sifat agresif (Winberg \& Nilsson, 1993; Young, 1996). Pada telestoi, Munro (1986) dan Maler \& Ellis (1987) menemukan bahwa injeksi serotonin (5-hydroxytryptamine, 5-HT) menghambat sifat agresif pada ikan cichlid, Aequidens pulcher, dan ikan knifefish, Apteronotus leptorhynchus. Adam et al. (1996) melaporkan bahwa sifat agresif ikan betina firemouth cichlid, Thorichthys meeki distimulir oleh injeksi intraperitoneal dengan pchlorophenylalanine (PCPA), 5-HT synthesis inhibitor.

Triptopan merupakan salah satu jenis asam amino esensial yang berfungsi sebagai prekursor 5-HT
(Leathwood, 1987). Pada mamalia dan burung, suplementasi triptopan dalam pakan dapat meningkatkan sintesis 5-HT dalam otak (Denbow et al., 1993; Cleare \& Bond, 1995; Savory et al., 1999). Beberapa hasil penelitian menunjukkan bahwa tingkat kanibalisme dapat ditekan dengan penambahan 0,5\% triptopan dalam pakan juvenil ikan kerapu lumpur, Epinephelus coioides (Hseu et al., 2003), dan 1,0\%dalam pakan kerapu macan, E. fuscoguttatus (Kamaruddin et al., 2007). Kandungan triptopan dalam bahan pakan umumnya rendah sehingga sering menjadi faktor pembatas pertumbuhan (Farhat \& Mukhtar, 2014). Selain berfungsi dalam sintesis protein tubuh, triptopan juga berperan dalam beberapa fungsi biologis seperti pengaturan nafsu makan, dan respons imunitas (Anonimous, 2015). Berdasarkan hal tersebut, maka penelitian ini dilakukan untuk mendapatkan dosis optimum triptopan dalam pakan yang dapat meningkatkan sintasan (menekan sifat kanibal) dan meningkatkan laju pertumbuhan krablet kepiting bakau selama masa pendederan.

\section{BAHAN DAN METODE}

\section{Produksi Krablet Kepiting Bakau}

Hewan uji yang digunakan dalam penelitian ini adalah krablet kepiting bakau yang berbobot rata-rata $0,039 \pm 0,004 \mathrm{~g}$ dan lebar karapas 3,50 $\pm 0,62 \mathrm{~mm}$ sebanyak 750 ekor. Hewan uji tersebut diperoleh dari hasil perbenihan sendiri dengan mengikuti prosedur standar pembenihan kepiting bakau yang ada saat ini (Shelley \& Lovatelli, 2011; Gunarto et al., 2014).

\section{Pakan Uji}

Empat pakan diformula melalui penambahan Ltriptopan pada empat dosis berbeda yaitu: $0 \%, 0,25 \%$ $0,50 \%$ dan $1 \%$ serta pakan kontrol berupa rebon kering, dan didapatkan kandungan triptopan pakan bertutur-turut: 0,41\%(A); 0,52\%(B); 0,67\%(C); 0,96\% (D); dan 0,79\%(pakan rebon, E). Pakan dalam bentuk pelet tersebut memiliki kandungan iso -protein sekitar $46 \%$ lemak sekitar $8 \%$ dan iso-energi sekitar 18,5 MJ/kg (Catacutan, 2002; Unnikrishnan \& Paulraj, 2010). Komposisi bahan dan hasil analisis proksimat pakan uji disajikan pada Tabel 1.

\section{Kondisi Pemeliharaan}

Krablet dipelihara menggunakan 15 unit fibre glass masing-masing berukuran $1 \mathrm{~m} \times 1 \mathrm{~m} \times 0,5 \mathrm{~m}$. Wadah pemeliharaan dilengkapi dengan shelter berupa lima potongan waring hitam berukuran $40 \mathrm{~cm} \times 40 \mathrm{~cm}$, dan $400 \mathrm{~g}$ rumput laut Gracilaria sp. untuk memperluas permukaan agar dapat ditempati krablet. Krablet ditebar dengan kepadatan 50 ekor/bak. Selama lima minggu pemeliharaan, krablet diberi pakan uji 
Tabel 1. Komposisi bahan dan komposisi proksimat pakan uji (\%bobot kering)

Table 1. Ingredient and proximate composition of the experimental diets (\%dry)

\begin{tabular}{lccccc}
\hline \multirow{2}{*}{\multicolumn{1}{c}{ Bahan }} & \multicolumn{5}{c}{ Pakan uji (Test diets) } \\
\cline { 2 - 7 } & A & B & C & D & E \\
\hline Tepung ikan lokal (Fish meal) & 38 & 38 & 38 & 38 & \\
Tepung cumi (Squid meal) & 10 & 10 & 10 & 10 & \\
Tepung rebon (Mysid meal) & 15 & 15 & 15 & 15 & \\
Tepung terigu (Wheat meal) & 17 & 17 & 17 & 17 & \\
Tepung tapioka (Tapioca meal) & 5 & 4.75 & 4.5 & 4.0 & \\
Tepung rumput laut (Gracilaria sp.) & 3 & 3 & 3 & 3 & \\
Minyak ikan (Fish oil) & 3 & 3 & 3 & 3 & Rebon \\
Minyak kedele (Soybean oil) & 1 & 1 & 1 & 1 & M ysid \\
Vitamin premix 1) & 3 & 3 & 3 & 3 & \\
Mineral premix & 3 & 3 & 3 & 3 & \\
Kuning telur (Egg yolk) & 0.5 & 0.5 & 0.5 & 0.5 & \\
Lecithine & 1 & 1 & 1 & 1 & \\
Carophyll pink & 0.5 & 0.5 & 0.5 & 0.5 & \\
L-triptophan & 0 & 0.25 & 0.50 & 1.0 & \\
\hline
\end{tabular}

Komposisi proksimat dan kandungan triptopan

Proximate composition and tryptophan content:

\begin{tabular}{|c|c|c|c|c|c|}
\hline Protein kasar (Crude protein) & 46.5 & 46.8 & 46.9 & 46.5 & 65.3 \\
\hline Lemak (Lipid) & 8.6 & 8.1 & 8.4 & 8.1 & 6.4 \\
\hline Serat kasar (Crude fibre) & 2.3 & 2.8 & 2.2 & 2.5 & 4.1 \\
\hline Abu (Ash) & 11.8 & 11.6 & 11.4 & 11.9 & 16 \\
\hline BETN $(N F E)^{3)}$ & 30.8 & 30.7 & 31 & 31 & 8.1 \\
\hline Energi total (Gross energy) $(\mathrm{MJ} / \mathrm{kg})^{4}$ & 18.6 & 18.4 & 18.6 & 18.4 & 17.9 \\
\hline Rasio protein/energi (Protein/energy ratio ) & 25 & 25.4 & 25.2 & 25.3 & 36.6 \\
\hline Triptopan (Tryptophan) & 0.41 & 0.52 & 0.67 & 0.96 & 0.79 \\
\hline
\end{tabular}

Keterangan (Note):

1) Vitamin premix (dalam 1 kg pakan (diet)): Vit. A90.000 IU; Vit. D3 30.000 IU; Vit. K3 36 mg; Vit. E $225 \mathrm{mg}$; Vit. B 90 mg; Vit B 135 mg; Vit B 60 mg; Vit B 90 mg; Vit. C 240 mg; Calcium D-Pentathenate 120 mg; Folic acid 45 mg, Biotin 300 mg, Inositol 375 mg, Nicotinamide $600 \mathrm{mg}$, Cholin chloride $450 \mathrm{mg}$

2) Mineral premix (dalam $1 \mathrm{~kg}$ pakan (diet)): $\mathrm{FeCl}_{3} \cdot 4 \mathrm{H}_{2} \mathrm{O} 1660 \mathrm{mg} ; \mathrm{ZnSO}_{4} 100 \mathrm{mg} ; \mathrm{MnSO}_{4}, 67,5$ mg; $\mathrm{CuSO}_{4} 20 \mathrm{mg} ; \mathrm{KI} 1.5 \mathrm{mg}, \mathrm{CoSO}_{4} .7 \mathrm{H}_{2} \mathrm{O} 1,0 \mathrm{mg} ; \mathrm{Ca}\left(\mathrm{H}_{2} \mathrm{PO}_{4}\right) 11.000 \mathrm{mg} ; \mathrm{MgSO}_{4} .7 \mathrm{H} 2 \mathrm{O}$ $13.000 \mathrm{mg} ; \mathrm{K}_{2} \mathrm{HPO}_{4} 8.000 \mathrm{mg}$

3) BETN (Bahan ekstrak tanpa nitrogen)/Nitrogen-free extract (NFE)

4) Energi total dihitung berdasarkan nilai konversi untuk protein, lemak, dan BETN berturutturut 21,3; 39,5; dan 17,2 MJ/kg (Gross energy calculation from the determined protein, lipid, and NFE of the diet using conversion coefficiency of $21.3 ; 39.5$, and $17.2 \mathrm{MJ} / \mathrm{kg}$ respectively) (Cuzon \& Guillume, 1997)

sebanyak 30\% hingga 15\% secara menurun, dengan frekuensi pemberian pakan sebanyak tiga kali sehari (pagi, sore, dan malam hari). Sisa pakan dibersihkan dan dikumpulkan sebelum pemberian pakan berikutnya untuk perhitungan konsumsi pakan. Sampling pertumbuhan dan sintasan krablet dilakukan setiap minggu untuk menyesuaikan dosis pemberian pakannya. Peubah yang diamati meliputi laju pertumbuhan, sintasan, dan distribusi ukuran hewan uji, tingkat konsumsi pakan harian, rasio konversi pakan, rasio efisiensi protein, dan komposisi kimia tubuh kepiting. Untuk mempertahankan kualitas media pemeliharaan, maka dilakukan pergantian air sebanyak 20\%30\%setiap hari. Selama pemeliharaan, kisaran nilai kualitas air terdiri atas salinitas 25-30 ppt; suhu air $26,10^{\circ} \mathrm{C}-29,0^{\circ} \mathrm{C}$; pH 7,6-8,0; oksigen terlarut 4,50-5,61 mg/L; amoniak nitrogen total (TAN) 0,1161-1,8797 mg/L; nitrit 0,1372-4,3510 mg/L; nitrat 1,2310-7,4875 mg/L; alkalinitas 117,6-190,5 mg/L; dan besi tersedia 0,0010-0,0045 mg/L dan dianggap cukup 
layak bagi kehidupan krablet kepiting bakau (Abiera et al., 2007; Rodriguez et al., 2007; Ut et al., 2007; Shelley \& Lovatelli, 2011).

\section{Perhitungan Respons Pertumbuhan dan Pemanfaatan Pakan Uji}

Penilaian kinerja pertumbuhan dan tingkat pemanfaatan pakan uji oleh hewan uji didasarkan atas beberapa peubah seperti:

Laju pertumbuhan spesifik (SGR) krablet dengan formula sebagai berikut (Schulz et al., 2005):

$$
\text { SGR (\%per hari })=100 \times\left(\frac{\ln W t-\ln W_{0}}{t}\right)
$$

di mana: In = logaritma alamiah,

$\mathrm{Wt}=$ bobot krablet pada akhir penelitian

Wo $=$ bobot krablet pada awal penelitian

$\mathrm{t}=$ jumlah hari pemeliharaan.

Pertambahan bobot dihitung dengan formula (Chu et al., 2014):

$$
\text { Pertambahan bobot }\left(\%=\frac{\left(\mathrm{Wt}-\mathrm{Wo}_{0}\right)}{(\mathrm{Wo})} \times 100\right.
$$

Tingkat konsumsi pakan harian (KPH) dihitung berdasarkan formula (Ozorio et al., 2009):

$$
\mathrm{KPH}(\%)=\frac{\text { Total konsumsi pakan }(\mathrm{g})}{[(\mathrm{Wt}+\mathrm{Wo}) / 2] \times \mathrm{t}} \times 100
$$

Rasio konversi pakan (FCR) (Unnikrishnan \& Paulraj, 2010):

$$
\mathrm{FCR}=\frac{\text { Total konsumsi pakan }(\mathrm{g})}{\text { Pertambahan bobot hewan uji (g) }}
$$
2014):

Rasio efisiensi protein (PER) (Mohseni \& Ozorio,

$$
\mathrm{PER}=\frac{\text { Pertambahan bobot hewan uji }(\mathrm{g})}{\text { Jumlah protein yang dikonsumsi }(\mathrm{g})}
$$

$$
\text { SR }\left(\%=\frac{\text { Jumlah hewan uji pada akhir penelitian }}{\text { Jumlah hewan uji pada awal penelitian }} \times 100\right.
$$

\section{Analisis Kimia dan Statistik}

Pada analisis proksimat pakan dan kepiting, sampel yang representative dianalisis berdasarkan AOAC (1999): bahan kering (DM) dikeringkan dengan oven pada suhu $105^{\circ} \mathrm{C}$ hingga bobot konstan, protein kasar dianalisis dengan micro-Kjeldahl, dan lemak dideterminasi secara gravimetrik dengan extraksi chloroform: metanol pada sampel, serat kasar dengan pemanasan yang disertai pencucian asam dan basa secara bergantian, dan abu dengan pembakaran dalam tanur pada suhu $550^{\circ} \mathrm{C}$ selama $24 \mathrm{jam}$.

Kandungan asam amino dianalisis dengan High Performance Liquid Chromatography (HPLC, Shimadzu type 20) di Laboratorium Terpadu IPB, Bogor. Analisis asam amino (kecuali triptopan) digunakan pereaksi pra kolom menggunakan ortoftlaldehida yang mengandung merkaptoetanol dalam suasana basa, kolom ultra techspere, fase mobil menggunakan bufer $\mathrm{A}$ ( $\mathrm{Na}$-asetat pH 6,5; Na-EDTA, metanol, dan THF yang dilarutkan dalam air HP) dan bufer B (metanol 95\%dan air HP), laju aliran fase mobil $1 \mathrm{~mL} / \mathrm{menit}$, dengan detektor flouresensi. Sementara triptopan dianalisis dengan metode HPLC khusus deteksi Ninhydrin postcolumnreaction.

Peubah kinerja pertumbuhan dan pemanfaatan pakan uji dianalisis ragam dan diuji lanjut dengan uji Beda Nyata Terkecil (BNT) (Steel \& Torrie, 1995). Sebelum analisis ragam, data dalam bentuk persentase ditransformasi ke logaritma. Distribusi ukuran hewan dan profil asam amino tubuh hewan uji dianalisis secara deskriptif.

\section{HASIL DAN BAHASAN}

Sintasan dan pertumbuhan krabet kepiting bakau selama lima minggu pendederan disajikan pada Tabel 2. Pada Tabel 2 dan Gambar 1 terlihat bahwa sintasan krablet yang didapatkan pada akhir penelitian tidak berbeda nyata $(P>0,05)$ di antara perlakuan. Bila diasumsikan bahwa krablet yang mati secara alami ditandai dengan adanya bangkai utuh di dalam bak (berdasarkan pengamatan yang dilakukan setiap pengambilan sisa pakan, jumlahnya $<2 \%$ bak), maka dapat dikatakan bahwa kematian krablet umumnya terjadi akibat kanibalisme (> 98\% $\mathrm{dbak}$ ). Asam amino triptopan sebagai precursor pembentukan serotonin, tampaknya belum memberikan pengaruh nyata terhadap penurunan tingkat agresifitas (kanibalisme) krablet kepiting bakau pada penelitian ini. Laranja et al. (2010) menemukan adanya peningkatan sintasan kepiting bakau yang diberi pakan mengandung triptopan 0,5\% 1,0\%dibandingkan pakan kontrol (kadar triptopan pakan 0,32\% tanpa penambahan L-triptopan) setelah pemeliharaan krablet selama 15 hari. Namun setelah pemeliharaan selama 30 hari, sintasan krablet kepiting bakau tersebut menjadi tidak berbeda nyata di antara pakan uji dan pakan kontrol. Lebih lanjut dilaporkan bahwa kadar serotonin dalam hemolim meningkat setelah kepiting saling menyerang, dan jika 
Tabel 2. Performansi pertumbuhan dan sintasan krablet kepiting bakau yang diberi pakan dengan kadar triptopan berbeda

Table 2. Growth performance and survival rate of mud crab crablet fed diet containing different levels of tryptophan

\begin{tabular}{|c|c|c|c|c|c|}
\hline \multirow{2}{*}{$\begin{array}{l}\text { Peubah } \\
\text { Variables }\end{array}$} & \multicolumn{5}{|c|}{ Pakan uji (Test diets) } \\
\hline & A & B & C & D & $\mathbf{E}$ \\
\hline $\begin{array}{l}\text { Bobot akhir rata-rata (g/ekor) } \\
\text { Final body weight (g/ind.) }\end{array}$ & $1.708 \pm 0.219$ & $1.828 \pm 0.17$ & $1.929 \pm 0.061$ & $1.843 \pm 0.2$ & $1.848 \pm 0.05$ \\
\hline $\begin{array}{l}\text { Laju pertumbuhan spesifik (\%hari) } \\
\text { Specific growth rate (\%/day) }\end{array}$ & $9.33 \pm 0.50^{\mathrm{a}}$ & $9.70 \pm 0.59^{\mathrm{ab}}$ & $10.30 \pm 0.30^{b}$ & $9.67 \pm 0.26^{\mathrm{ab}}$ & $9.74 \pm 0.74^{\mathrm{ab}}$ \\
\hline $\begin{array}{l}\text { Pertambahan bobot } \\
\text { Weight gain }(\%)\end{array}$ & $4235 \pm 438^{\mathrm{a}}$ & $4541 \pm 304^{\mathrm{ab}}$ & $4804 \pm 75^{b}$ & $4579 \pm 396^{\mathrm{ab}}$ & $4602 \pm 241^{\mathrm{ab}}$ \\
\hline $\begin{array}{l}\text { Lebar karapas akhir rata-rata } \\
\text { Final carapace width }(\mathrm{mm})\end{array}$ & $21.4 \pm 1.4^{\mathrm{a}}$ & $22.6 \pm 2.7^{\mathrm{a}}$ & $23.1 \pm 1.8^{\mathrm{a}}$ & $22.1 \pm 2.5^{\mathrm{a}}$ & $22.6 \pm 2.0^{a}$ \\
\hline $\begin{array}{l}\text { Panjang karapas akhir } \\
\text { Final carapace length }(\mathrm{mm})\end{array}$ & $14.8 \pm 0.6^{a}$ & $15.6 \pm 0.9^{a}$ & $15.9 \pm 0.6^{\mathrm{a}}$ & $15.4 \pm 1.3^{\mathrm{a}}$ & $15.5 \pm 0.7^{\mathrm{a}}$ \\
\hline $\begin{array}{l}\text { Sintasan } \\
\text { Survival rate }(\%)\end{array}$ & $56.7 \pm 15.5^{\mathrm{a}}$ & $58.7 \pm 7.6^{\mathrm{a}}$ & $68.0 \pm 6.9^{a}$ & $57.3 \pm 1.2^{\mathrm{a}}$ & $59.3 \pm 12.9^{a}$ \\
\hline
\end{tabular}

Keterangan (Note): Nilai dalam baris yang sama diikuti oleh superscript yang sama menunjukkan tidak berbeda nyata $(P>0,05)$ Value in the same row followed by the same superscript are not significantly different $(P>0.05)$

tidak terjadi penyerangan, dideteksi kadar serotonin dalam hemolim kepiting relatif sama di antara yang diberi pakan uji dan yang diberi pakan kontrol. Bila dihubungkan dengan pola sintasan krablet pada penelitian ini (Gambar 1), terlihat bahwa pada dua minggu pertama, tingkat kematian krablet masih cukup rendah dan tidak berbeda nyata $(P>0,05)$ di antara perlakuan. Kematian (umumnya kanibalisme) mulai tinggi pada minggu ketiga hingga akhir masa pendederan, namun tidak berbeda nyata $(P>0,05)$ di antara perlakuan. Hal yang berbeda dilaporkan oleh Hseu et al. (2003) yaitu dengan pemberian pakan yang disuplementasi triptopan sebanyak 0,25\% 1,0\%mampu menurunkan tingkat kanibalisme pada juvenil kerapu lumpur dan meningkatkan sintasannya. Demikian juga yang dilaporkan oleh Kamaruddin et al. (2007) bahwa suplementasi L-triptopan sebanyak 0,5\% 1,0\% dalam pakan mampu menekan tingkat kanibalisme juvenil kerapu lumpur. Namun demikian, pada penelitian ini sintasan rata-rata benih sebesar $68 \%$ yang diperoleh pada pemberian pakan mengandung 0,67\%triptopan lebih tinggi $8,7 \% 11,3 \%$ dari perlakuan lainnya, secara deskriptif cukup penting bagi kegiatan perbenihan dan pendederan kepiting bakau.

Pemberian pakan dengan kadar triptopan berbeda dalam pakan berpengaruh nyata $(P<0,05)$ terhadap laju pertumbuhan krablet kepiting bakau. Laju pertumbuhan spesifik dan pertambahan bobot tertinggi terjadi pada krablet yang diberi pakan dengan kandungan triptopan 0,67\% yang berbeda nyata
$(\mathrm{P}<0,05)$ dengan krablet yang diberi pakan dengan kandungan triptopan $0,41 \% \mathrm{Hal}$ ini menunjukkan bahwa asam amino triptopan dalam pakan uji ini berperan sebagai asam amino esensial yang menjadi faktor pembatas pertumbuhan krablet kepiting bakau. Asam amino triptopan merupakan salah satu asam amino esensial yang kandungannya terbatas dalam beberapa bahan pakan, dan sering menjadi faktor pembatas bagi pertumbuhan ikan (Farhat \& Mukhtar, 2014). Sementara hasil penelitian yang dilaporkan oleh Laranja et al. (2010) bahwa pakan yang mengandung asam amino triptopan $0,5 \%-1,0 \%$ cenderung menurunkan laju pertumbuhan kepiting bakau meskipun belum berbeda nyata dengan pakan kontrol (kandungan triptopan pakan 0,32\%. Penyebab respons pertumbuhan yang relatif berbeda dari kedua penelitian ini belum diketahui secara pasti, namun kemungkinan dari perbedaan komposisi dan kualitas bahan pakan yang digunakan, serta kondisi pemeliharaan hewan uji. Pada penelitian ini juga digunakan pakan kontrol yang biasa digunakan dalam pendederan krablet kepiting bakau yaitu rebon kering yang memiliki kandungan triptopan sebanyak 0,79\% Respons pertumbuhan kepiting yang diberi pakan rebon tersebut masih relatif sama dengan yang diberi pakan buatan yang mengandung triptopan 0,52\%0,96\% Hal ini menunjukkan bahwa pertumbuhan krablet kepiting bakau yang diberi pakan buatan dengan kandungan triptopan 0,52\%0,96\%tersebut masih normal. Laju pertumbuhan bobot spesifik krablet kepiting 
bakau yang didapatkan pada penelitian ini juga lebih cepat $(9,3 \% 10,3 \%$ hari) dibandingkan yang didapatkan oleh Laranja et al. (2010) yaitu 3,98\% 6,06\%/hari dengan ukuran krablet awal sekitar 0,16 g. Pada udang vaname, dilaporkan terjadi peningkatan secara nyata pada laju pertumbuhan, rasio efisiensi protein, dan sintasan udang dengan meningkatnya dosis suplementasi asam amino triptopan 0,12\% hingga 0,6\%dalam pakan (Su et al., 2015). Peningkatan laju pertumbuhan dan sintasan juga terjadi pada udang cerax, crayfish (Astacus leptodactylus) yang diberi pakan dengan suplementasi triptopan sebanyak 1,0\%dibandingkan udang cerax yang diberi pakan tanpa suplementasi triptopan (kadar triptopan pakan 0,33\% (Harhoglu et al., 2014). Sementara pada ikan kerapu macan yang diberi pakan dengan suplementasi L-triptopan sebanyak 0,25\% 1,0\% belum menunjukkan adanya peningkatan Iaju pertumbuhan ikan selama masa pendederan (Kamaruddin et al., 2007). Tetapi pemberian pakan yang disuplementasi triptopan sebanyak 0,25\% 1,0\% telah menurunkan laju pertumbuhan juvenil kerapu lumpur (Hseu et al., 2003). Informasi tentang kebutuhan asam amino triptopan dalam pakan kepiting bakau masih sangat terbatas. Pada udang windu, Akiyama et al. (1991) merekomendasikan kandungan triptopan dalam pakan sebanyak 0,8\%terhadap protein. Hal ini menunjukkan bahwa kadar asam amino triptopan yang terbaik dalam penelitian ini sudah cukup tinggi yaitu $0,67 \%$ bobot kering pakan atau $1,43 \%$ terhadap protein pakan. Berdasarkan hasil penelitian Unnikrishnan \& Paulraj (2010) yang menyimpulkan bahwa kebutuhan optimum protein dalam pakan untuk pertumbuhan dan retensi protein terbaik untuk juvenil kepiting bakau adalah $47 \%$ dan pakan tersebut mengandung asam amino triptopan sekitar 2,0\% kondisi pakan. Pada beberapa ikan budidaya, kebutuhan optimum kandungan asam amino triptopan dalam pakan berkisar antara 0,5\% 1,4\% terhadap protein (Wilson, 2002; Ahmed, 2012).

Tingkat konsumsi pakan harian krablet kepiting bakau selama lima minggu pendederan tidak menunjukkan perbedaan nyata $(P>0,05)$ di antara perlakuan (Gambar 2). Hal ini mengindikasikan bahwa penambahan asam amino triptopan dalam pakan uji tersebut tidak menurunkan dan tidak menambah nafsu makan krablet kepiting bakau. Hasil penelitian ini sama dengan yang dilaporkan oleh Kamaruddin et al. (2007) bahwa tingkat konsumsi pakan harian juvenil kerapu macan relatif sama saat diberi pakan dengan jumlah penambahan asam amino triptopan sebanyak 0\% $1 \%$ Sementara adanya kecederungan penurunan Iaju pertumbuhan juvenil kepiting bakau yang laporkan oleh Laranja et al. (2010) dengan pemberian pakan yang mengandungan triptopan 0,5\% 1,0\% diperkirakan karena adanya penurunan konsumsi pakan. Hal yang sama juga dilaporkan oleh Hseu et al. (2003) pada ikan kerapu lumpur. Pinchasov et al. (1989) melaporkan bahwa peningkatan serotonergik otak pada mamalia dan burung cenderung menurunkan tingkat konsumsi pakannya. Pada ikan goldfish, Carassius auratus, penyuntikan serotonin pada intra cerebral ventricular secara nyata menurunkan konsumsi pakannya (De Pedro et al., 1998).

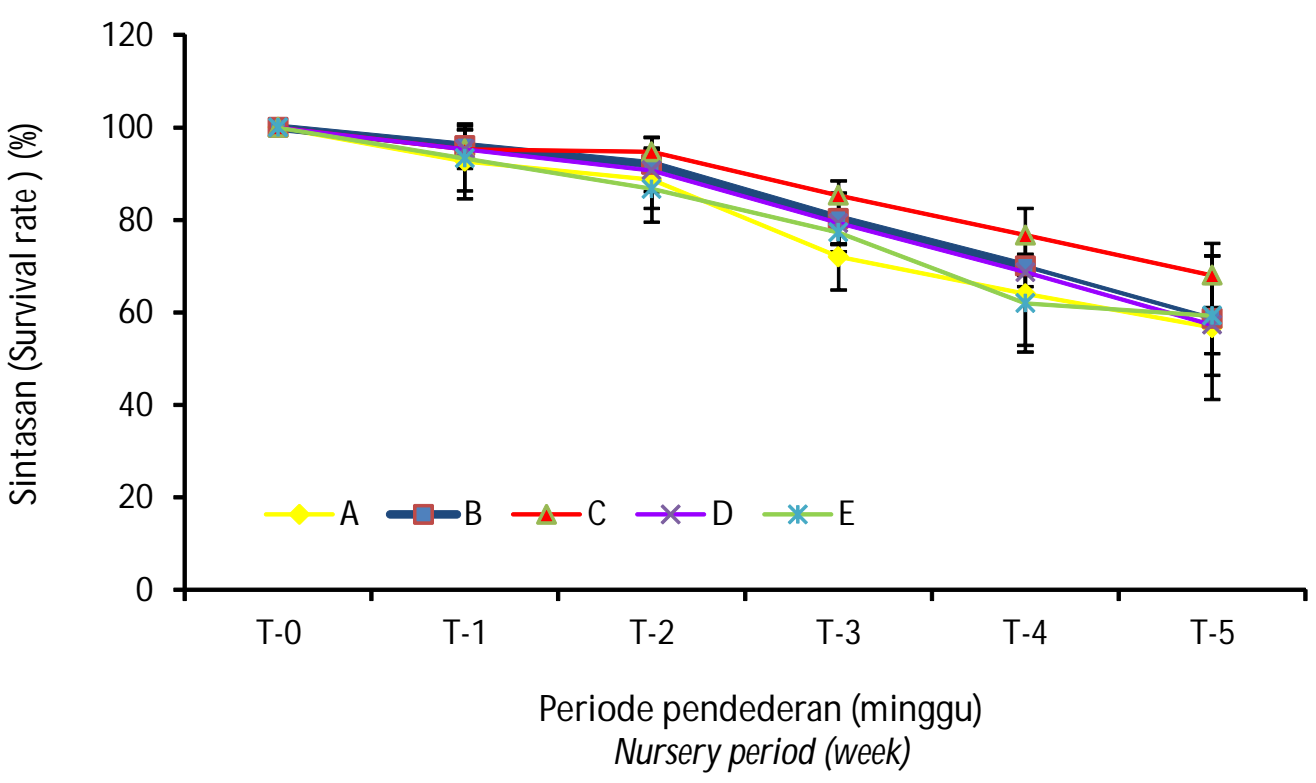

Gambar 1. Pola sintasan krablet kepiting bakau yang diberi pakan dengan kadar triptopan berbeda

Figure 1. Survival rate pattern of mud crab crabletfed diet containing different levels of tryptophan 


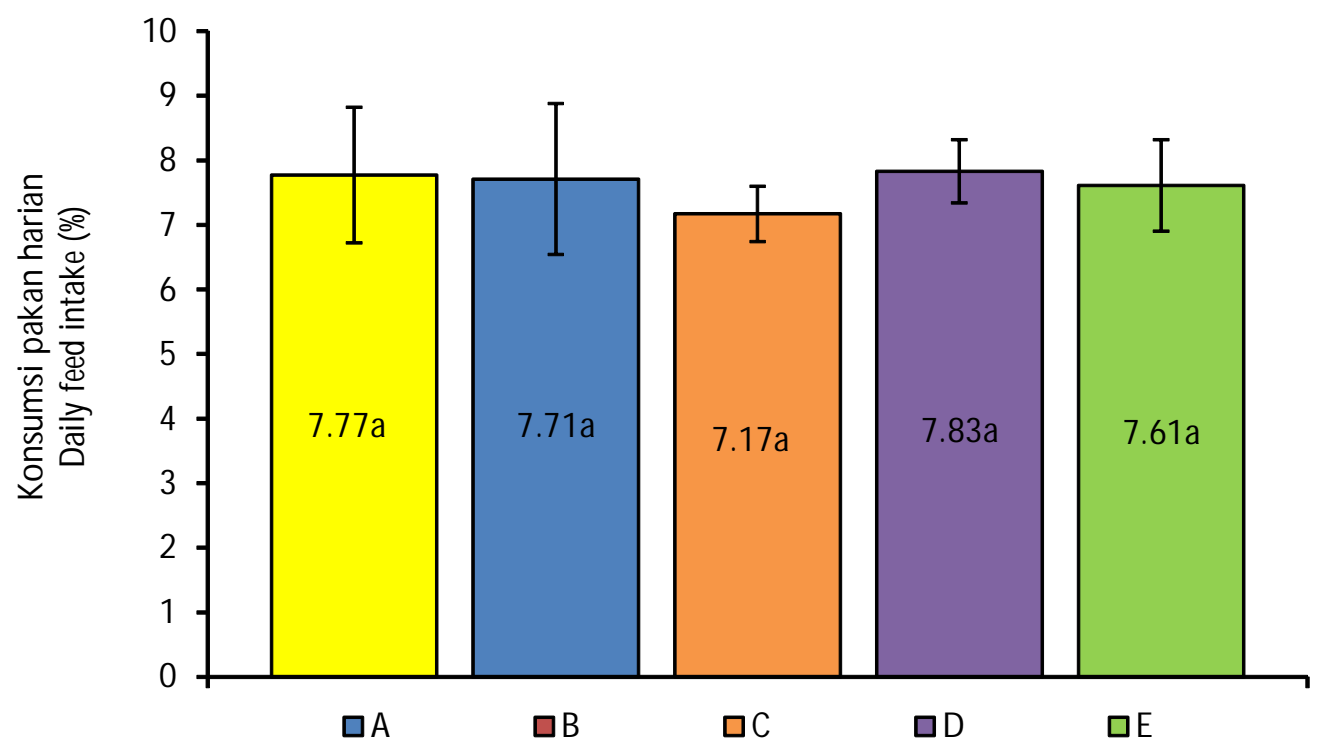

Gambar 2. Tingkat konsumsi pakan harian krablet kepiting bakau yang diberi pakan dengan kadar triptopan berbeda

Figure 2. Daily feed intake of mud crab crablet fed diet containing different levels of tryptophan

Salah satu peubah yang sering digunakan dalam menilai tingkat pemanfaatan pakan adalah rasio konversi pakan. Pada Gambar 3 terlihat bahwa rasio konversi pakan tidak berbeda nyata $(P>0,05)$ di antara perlakuan. Meskipun laju pertumbuhan krablet kepiting bakau yang diberi pakan dengan kandungan asam amino triptopan sebanyak $0,67 \%$ secara nyata lebih tinggi dibandingkan krablet kepiting bakau yang diberi pakan yang mengandung asam amino triptopan $0,41 \%$ namun tingkat konsumsi pakan hariannya relatif sama, serta nilai variasi yang cukup tinggi dalam ulangan sehingga rasio konversi pakan di antara perlakuan tersebut masih relatif sama.

Pada rasio efisiensi protein pakan terdapat perbedaan yang nyata $(P<0,05)$ di antara perlakuan (Gambar 3). Krablet kepiting bakau yang diberi pakan

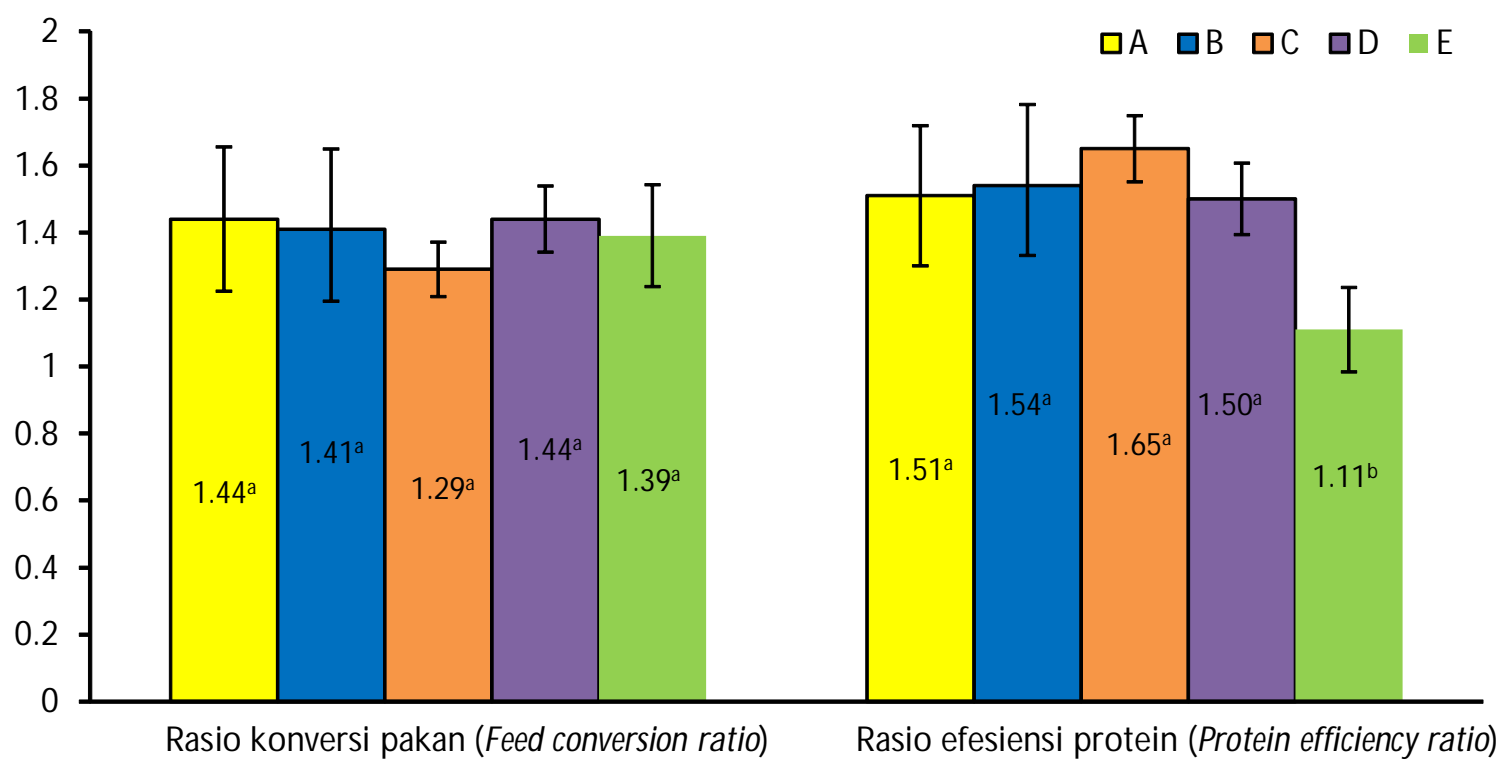

Gambar 3. Rasio konversi pakan (i) dan rasio efisiensi protein (ii) pada krablet kepiting bakau yang diberi pakan dengan kadar triptopan berbeda

Figure 3. Feed conversion ratio (i) and protein efficiency ratio (ii) of mud crabcrablet fed diet containing different levels of tryptophan 


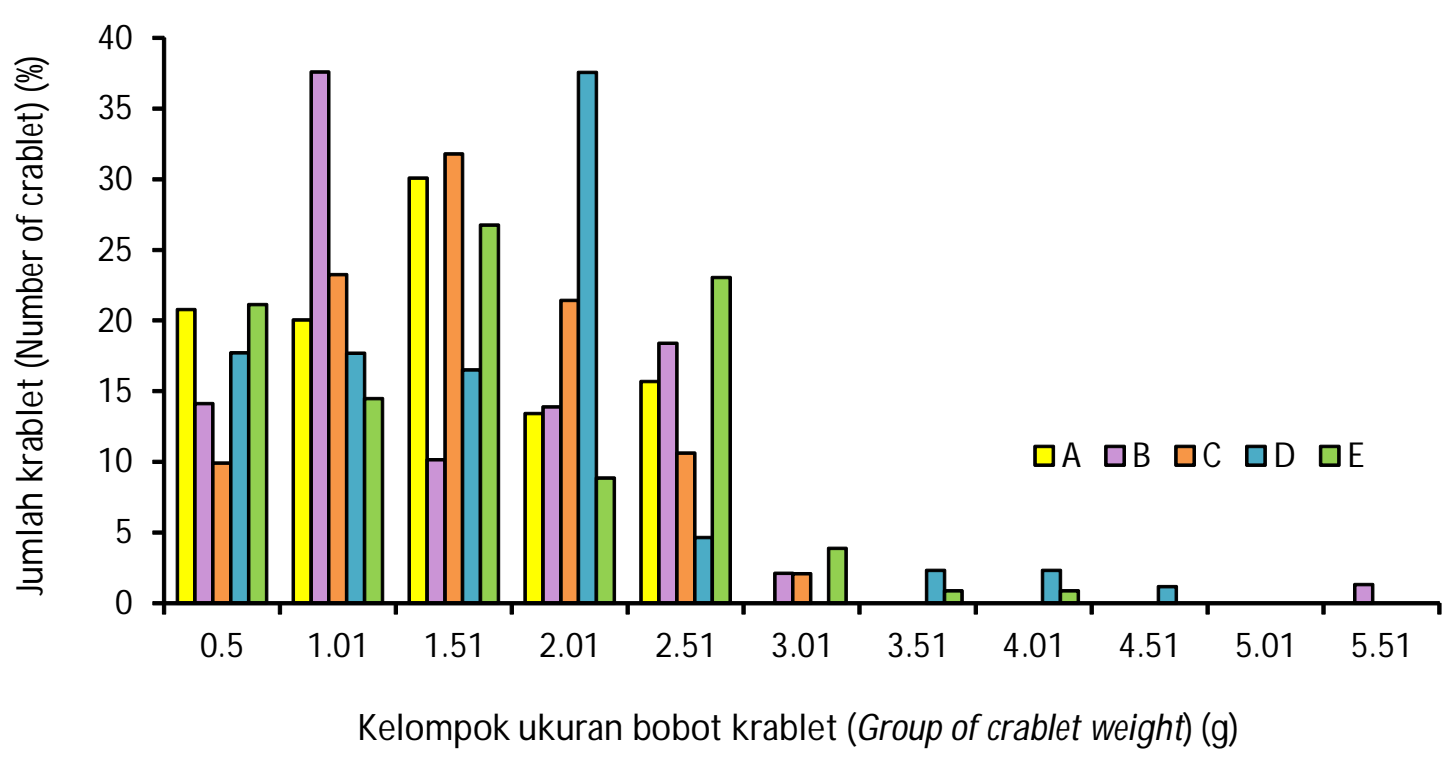

Gambar 4. Distribusi ukuran krablet kepiting bakau yang diberi pakan dengan kadar triptopan

Figure 4. Distribution of body weight of mud crab crablet fed diet containing different levels of tryptophan

buatan memiliki rasio efisiensi protein yang lebih tinggi dibandingkan krablet kepiting bakau yang diberi pakan rebon kering. Hal ini menunjukkan bahwa pemanfaatan protein untuk pertumbuhan dalam pakan buatan tersebut memiliki proporsi yang lebih tinggi dibandingkan dalam pakan rebon kering. Unnikrishnan \& Paulraj (2010) mendapatkan rasio efisiensi protein sekitar 1,47 pada pemberian pakan berprotein $45 \%$ untuk juvenil kepiting bakau. Nilai efisiensi protein tersebut sedikit lebih rendah daripada yang didapatkan pada penelitian ini yang menggunakan pakan buatan namun lebih tinggi dibandingkan yang menggunakan pakan rebon kering. Hal ini juga menunjukkan bahwa potensi jumlah limbah nitrogen dari pakan pelet tersebut cenderung lebih rendah dibandingkan potensi jumlah limbah nitrogen dari pakan rebon kering jika diberikan dalam jumlah dan waktu yang tepat dalam pendederan krablet kepiting bakau.

Pada Gambar 4 terlihat bahwa secara umum ukuran bobot krablet kepiting bakau setelah pendederan selama lima minggu berada pada kisaran antara $0,5 \mathrm{~g}$ hingga 6,51 g; merupakan tingkat variasi ukuran bo bot yang cukup lebar. Variasi ukuran individu krablet yang cukup lebar ini dapat memicu tingkat kanibalisme yang sangat tinggi. Kisaran ukuran krablet yang paling sempit (lebih seragam) cenderung terjadi pada krablet yang diberi pakan dengan kandungan triptophan $0,67 \%$ sementara yang terlebar terjadi pada krablet yang diberi pakan dengan kandungan triptophan 0,52\% Dalam kegiatan pendederan, untuk menekan tingkat kanibalisme krablet kepiting bakau, selain dengan pemberian pakan yang tepat jumlah dan mutu, perlu juga dilakukan grading (penyeragaman ukuran) setiap minggu.

Profil asam amino total tubuh krablet kepiting bakau disajikan pada Tabel 3. Pada Tabel 3 terlihat bahwa profil asam amino (baik esensial maupun nonesensial) krablet kepiting bakau setelah pemeliharaan selama lima minggu mengalami variasi namun relatif kecil. Hal ini terkait dengan profil asam amino pakan uji dari bahan pakan yang digunakan sama (selain triptopan, Tabel 1) dan jumlah konsumsi pakan selama pendederan. Secara khusus kandungan asam amino triptopan krablet kepiting bakau tersebut juga mengalami sedikit dinamika dengan kecenderungan meningkat dengan meningkatnya kandungan triptopan pakan uji.

Komposisi proksimat krablet kepiting bakau setelah pendederan selama lima minggu pemberian pakan uji disajikan pada Tabel 4. Pada Tabel 4 terlihat bahwa kandungan protein kasar, lemak, abu, serat kasar, dan bahan ekstrak tanpa nitrogen krablet kepiting bakau relatif sama $(P>0,05)$ di antara perlakuan. Hal ini menunjukkan bahwa semua pakan uji memberikan kualitas nutrisi (makro nutrien) yang lelatif sama dalam tubuh krablet. Namun demikian, krablet yang diberi pakan rebon kering cenderung memiliki kandungan lemak yang agak rendah dan kadar abu yang agak tinggi. Hal ini kemungkinan berkaitan dengan kandungan lemak pakan rebon yang lebih rendah. 
Tabel 3. Profil asam amino (\% protein) tubuh krablet kepiting yang diberi pakan dengan kadar triptopan berbeda

Table 3. Amino acid profile (\% protein) of whole body mud crab crablet fed diets containing different levels of tryptophan

\begin{tabular}{lccccc}
\hline \multirow{2}{*}{$\begin{array}{l}\text { Jenis asam amino } \\
\text { Amino acid kinds }\end{array}$} & \multicolumn{5}{c}{ Pakan uji (Test diets) } \\
\cline { 2 - 6 } & A & B & C & D & E \\
\hline Aspartic acid & 7.62 & 8.86 & 9.33 & 9.29 & 8.99 \\
Glutamic acid & 14.02 & 13.04 & 13.64 & 14.12 & 13.62 \\
Serine & 2.61 & 2.87 & 3.34 & 2.93 & 3.06 \\
Histidine & 2.40 & 2.45 & 2.43 & 2.37 & 2.28 \\
Glycine & 6.13 & 6.07 & 6.71 & 7.14 & 8.23 \\
Threonine & 3.08 & 3.45 & 4.25 & 4.05 & 4.17 \\
Arginine & 5.86 & 6.60 & 7.36 & 6.92 & 6.79 \\
Alanine & 4.90 & 4.76 & 4.85 & 5.24 & 4.72 \\
Tyrosine & 3.35 & 3.40 & 3.80 & 3.63 & 3.76 \\
Methionine & 2.81 & 2.20 & 2.40 & 2.37 & 2.38 \\
Valine & 4.17 & 4.82 & 4.97 & 5.05 & 5.14 \\
Phenylalanine & 3.62 & 4.09 & 4.14 & 4.41 & 4.22 \\
Heucine & 3.65 & 4.37 & 4.48 & 4.56 & 4.61 \\
Leucine & 5.28 & 6.18 & 6.45 & 6.56 & 6.68 \\
Lysine & 4.79 & 6.30 & 5.94 & 7.59 & 6.29 \\
Tryptophan & 1.90 & 1.95 & 1.97 & 2.23 & 2.10 \\
\hline
\end{tabular}

Tabel 4. Komposisi proksimat nutrea dalam tubuh krablet kepiting bakau yang diberi pakan dengan kadar triptopan berbeda

Table 4. Whole body proximate composition of nutrients on mud crab crablet fed diet containing different levels of tryptophan

\begin{tabular}{lccccc}
\hline \multirow{2}{*}{$\begin{array}{c}\text { Nutrien } \\
\text { Nutrient }\end{array}$} & \multicolumn{5}{c}{ Pakan uji (Test diets) } \\
\cline { 2 - 6 } & A & B & C & D & E \\
\hline Protein kasar (Crude protein) & $38.2 \pm 0.8^{\mathrm{a}}$ & $37.5 \pm 0.8^{\mathrm{a}}$ & $36.8 \pm 1.2^{\mathrm{a}}$ & $37.4 \pm 0.8^{\mathrm{a}}$ & $37.7 \pm 1.0^{\mathrm{a}}$ \\
Lemak (Lipid) & $8.0 \pm 0.7^{\mathrm{a}}$ & $9.2 \pm 1.0^{\mathrm{a}}$ & $9.5 \pm 1.1^{\mathrm{a}}$ & $9.1 \pm 1.3^{\mathrm{a}}$ & $7.7 \pm 1.3^{\mathrm{a}}$ \\
Serat kasar (Crude fibre) & $11.3 \pm 1.3^{\mathrm{a}}$ & $10.4 \pm 0.9^{\mathrm{a}}$ & $10.7 \pm 1.1^{\mathrm{a}}$ & $10.4 \pm 1.4^{\mathrm{a}}$ & $11.5 \pm 0.7^{\mathrm{a}}$ \\
Abu (Ash) & $29.9 \pm 1.3^{\mathrm{a}}$ & $28.4 \pm 0.8^{\mathrm{a}}$ & $27.9 \pm 1.7^{\mathrm{a}}$ & $28.4 \pm 1.1^{\mathrm{a}}$ & $30.1 \pm 1.5^{\mathrm{a}}$ \\
BETN (NFE) & $12.7 \pm 2.1^{\mathrm{a}}$ & $14.4 \pm 1.9^{\mathrm{a}}$ & $15.0 \pm 2.7^{\mathrm{a}}$ & $14.7 \pm 0.8^{\mathrm{a}}$ & $13.1 \pm 1.9^{\mathrm{a}}$ \\
\hline
\end{tabular}

Keterangan (Note): Nilai dalam baris yang sama di ikuti oleh superscript yang sama menunjukkan tidak berbeda nyata $(P>0,05)$ (Means in the same row followed by the same superscript are not significantly different $(P>0.05))$

Pakan yang mengandung asam amino triptopan sebanyak $0,67 \%$ secara umum cenderung memiliki performa pertumbuhan dan pemanfaatan pakan yang lebih baik dibandingkan pakan uji lainya. Hal ini menunjukkan bahwa kandungan asam amino triptopan sebanyak $0,67 \%$ dalam pakan cenderung memberikan laju pertumbuhan dan pemanfaatan pakan yang optimum dalam pendederan krablet kepiting bakau.

\section{KESIMPULAN}

Kandungan asam amino triptopan dalam pakan berpengaruh terhadap pertumbuhan krablet kepiting bakau dan kandungan sebanyak 0,67\% (penambahan $0,5 \%$ triptopan dalam pakan) adalah optimum. Namun demikian kandungan triptopan pakan 0,41\%0,96\%tidak berpengaruh terhadap sintasan kepiting bakau karena tingkat kanibalisme yang tetap tinggi. 


\section{UCAPAN TERIMA KASIH}

Penelitian ini dibiayai oleh DIPA T.A. 2015 Balai Penelitian dan Pengembangan Budidaya Air Payau. Penulis mengucapkan terima kasih kepada Saudara Tamsil, Rosni, Dian Wahyuni Basri, Muh. Saleh, Muh. Danial, dan Muh. Rizal atas segala bantuannya dalam pelaksanaan kegiatan penelitian ini baik di laboratorium maupun di lapangan.

\section{DAFTAR ACUAN}

Abiera, M.L.S., Estepa, F.P., \& Gonzales, G.A. (2007). Acute toxicity of nitrite to mud crab Scylla serrata (Forsskal) larvae. Aquaculture Research, 38, 14951499.

Adams, C.F., Liley, N.R., \& Gorzalka, B.B. (1996). PCPA increases aggresion in male firemouth cichlids. Pharmacology, 53, 328-330.

Ahmed, I. (2012). Dietary amino acid L-tryptophan requirement of fingerling Indian catfish, Heteropneustes fossilis (Bloch), estimated by growth and haemato-biochemical parameters. Fish Physiology and Biochemistry, 38, 1195-1209.

Akiyama, D.M., Dominy, W.G., \& Lawrence, A.L. (1991). Penaeid shrimp nutrition for the commercial feed industry revised. In Akiyama, D.M. \& Tan, R.K.H. (Eds.). Proceeding of the Aquaculture Feed Processing and Nutrition Workshop, Thailand and Indonesia, Sept. 19-25. American Soybean Association, Singapore, p. 80-98.

Anonimous. (2015). Tryptophan, A key nutrient for growth and feed intake. http://ajinomotoeurolysine.com/tryptophan-requirements.html (diakses tanggal 21 Januari 2015).

AOAC International. (1999). Official methods of analysis. $16^{\text {th }}$ eds. Association of Official Analytical Chemists International. Gaithersberg, Maryland. USA, $1141 \mathrm{pp}$.

Catacutan, M.R. (2002). Growth and body composition of juvenile mud crab, Scylla serrata, feed different dietary protein and lipid levels and protein to energy ratio. Aquaculture, 208, 113-123.

Cerezo, R.B. (2001). Effect of different types of shelter on the production of mud crab Scylla serrata juvenile in concrete nursery tanks. Thesis. UPV, Miag-ao, Iloilo. Philippines, $70 \mathrm{pp}$.

Chu, Z.J., Gong, Y., Lin, Y.C., Yuan, Y.C., Cai, W.J., Gong, S.Y., \& Luo, Z. (2014). Optimal dietary methionine requirement of juvenile Chinese sucker, Myxocyprinus asiaticus. Aquaculture Nutrition, 20, 253-264.

Cleare, A.J., \& Bond, A.J. (1995). The effect tryptophan depletion and enhancement on subjective and behavioural aggression in normal male subjects. Psychopharmacology, 118, 505-511.
Cuzon, G., \& Guillaume, J. (1997). Energy and protein: energy ratio. In Crustacean Nutrition - Advances in Word Aquaculture VI (Eds.). D'Abraamo, L., Conklin, D., \& Akiyama, D.. p. 51-70. World Aquaculture Society, Los Angeles, USA.

Denbow, D.M., Hobbs, F.C., Hylet, R.M., Graham, P.P., \& Potter, L.M. (1993). Supplemental dietary L-tryptophan effects on growth, meat quality, and brain catecholamine and indoleamine concentrations in turkey. Br. Poult. Sci., 34, 715-724.

De Pedro, N., Pinillos, M.L., Valenciano, A.L., AlonsoBedate, M., \& Delgardo, M.J. (1998). Inhibitor effect of serotonin on feeding behavior in goldfish: involvement of CRF. Peptides, 19, 505-511.

Farhat, \& Mukhtar, A.K. (2014). Dietary L-tryptophan requirement of fingerling stinging catfish, Heteropneustes fossilis (Bloch). Aquaculture Research, 45, 1224-1235.

Folkvord, A. (1997). Otogeny of cannibalism in larva and juvenile fishes with special emphasis on Atlantic cod. In Chambers, R.C., \& Trippel, E.A. (Eds.). Early Life History and Recruitmen in fish Populations. Chapman \& Hall. London, p. 251-278.

Folkvord, A., \& Ottera, H. (1993). Effects of initial size distribution, day length and feeding frequency on growth, survival and cannibalism in juvenil Atlantic cod (Gadus morhua). Aquaculture, 114, 243260.

Gunarto. (2012). Pengaruh penggunaan shelter rumput laut, Gracilaria sp. pada pentokolan benih kepiting bakau, Scylla olivcea di laboratorium. Prosiding Seminar Nasional Perikanan Indonesia. Hasil Penelitian Perikanan dan Kelautan Tahun 2012. Budidaya Perikanan Jilid 2. Pusat Penelitian dan Pengabdian Masyarakat, Sekolah Tinggi Perikanan. Jakarta, hlm. 76-82.

Gunarto, Jompa, H., \& Parenrengi, A. (2014). Petunjuk teknis pembenihan kepiting bakau, Scylla spp. Balai Penelitian dan Pengembangan Budidaya Air Payau. Maros, $34 \mathrm{hlm}$.

Harhoglu, M.M., Harhoglu, A.G., Yonar, S.S., \& Duran, T.C. (2014). Effect of dietary L-tryptophan on agonistic behaviour, growth, and survival of freshwater crayfish, Astacus leptodactylus, Eschscholtz. Aquaculture International, 22, 733-748.

Hecht, T., \& Pienaar, A.G. (1993). A review of cannibalism and its implications in fish larviculture. J. World Aqua. Soc., 24, 246-261.

Hseu, J.R., Lu, F.I., Su, H.M., Wang, L.S., Tsai, C.L., \& Hwan, P.P. (2003). Effect of exogenous triptophan on cannibalism, survival and growth in juvenile grouper, E. coioides. Aquaculture, 218, 251-263.

Kamaruddin, Usman, \& Rachmansyah. (2007). Pengaruh penambahan triptophan terhadap tingkat 
kanibalisme, sintasan dan pertumbuhan juwana ikan kerapu macan, Epinephelusfuscoguttatus. Buku Pengembangan Teknologi Budidaya Perikanan. Pusat Riset Perikanan Budidaya. Jakarta, hlm. 301306.

Keenan, C.P., \& Blackshaw, A. (1999). Mud crab aquaculture and biology. Proceeding of an International Scientifc Forum held in Darwin, Australia on 21-24 April 1997. ACIAR Proceeding No. 78, 216 pp.

Laranja Jr., J.L.Q., Quinitio, E.T., Catacutan, M.R., \& Coloso, R.M. (2010). Effect of dietary L-triptophan on the agonistic behavior, growth and survival of juvenile mud crab Scylla serrata. Aquaculture, 310, 84-90.

Leathwood, P.D. (1987). Tryptophan availability and serotonin synthesis. Proc. Nutr. Soc., 46, 143-156.

Maler, L., \& Ellis, W.G. (1987). Inter-male aggressive signals in weakly electric fish are modulated by monoamines. Behav. Brain. Res., 25, 75-81.

Mohseni, M., \& Ozorio, R.O.A. (2014). Effects of dietary L-carnitine level on growth performance, body composition and antioxidant status in beluga (Huso huso L. 1758). Aquaculture Nutrition, 20, 477-485.

Munro, A.D. (1986). Effects of melatonin, serotonin, and naloxone on aggression in isolated cichlid fish (Aequiidens pulcher). J. Pineal Res., 3, 257-262.

Ozorio, R.O.A., Valente, L.M.P., Correia, S., PousaoFerreira, P., Damasceno-Oliveira, A., Escorcia, C., $\&$ Oliva-Teles, A. (2009). Protein requirement for maintenance and maximum growth of two-banded seabream (Diplodus vulgaris) juveniles. Aquaculture Nutrition, 15, 85-93.

Pinchasov, Y., Fancher, B.I., Burke, W.H., \& Jensen, L.S. (1989). Glycolic acid and tryptophan effects on feed intake and hypothalamic in chicks. Physiol. Behav., 45, 585-589.

Rodriguez, E.M., Parado-Estepa, F.D., \& Quinitio, E.T. (2007). Extension of nursery culture of Scylla serrata (Forsskall) juveniles in net cages and ponds. Aquaculture Research, 38, 1588-1592.

Savory, C.J., Mann, J.S., \& Macleod, M.G. (1999). Incidence of pecking damage in growing bantams in relation to food form, group size, stocking den- sity, dietary tryptophan concentrations and dietary protein source. Br. Poult. Sci., 40, 579-584.

Schulz, C., Knaus, M., Wirth, M., \& Rennert, B. (2005). Effect of varying dietary fatty acid profile on growth performance, fatty acid, body and tissue composition of juvenile pike perch (Sander lucioperca). Aquaculture Nutrition, 11, 403-413.

Shelley, C., \& Lovatelli, A. (2011). Mud crab aquaculture-a practical manual. FAO Fisheries and Aquaculture Technical Paper. No. 567. Rome, 78 pp.

Stell, R.G.D., \& Torry, J.H. (1995). Prinsip dan prosedur statistika. Alih bahasa: Bambang Sumantri. Gramedia Pustaka Utama. Jakarta, $748 \mathrm{hlm}$.

Su, Y-P., Guan L-Z., Xion, J.H., Xi, Q-Y., \& Zhang, Y-L. (2015). Effect of L-triptophan supplemented dietary on growth performance, and 5-HT and GABA levels in Litophenaeus vannamei. Aquaculture International, 23, 235-251.

Trino, A.T., \& Rodriguez, E.M. (2002). Pen culture of mud crab Scylla serrata in tidal flats reforested with mangrove trees. Aquaculture, 211, 125-134.

Unnikrishnan, U., \& Paulraj, R. (2010). Dietary protein requirements of giant mud crab Scylla serrata juveniles fed isoenergetic formulated diets having grade protein levels. Aquaculture Research, 41, 278-294.

Ut, V.N., Vay, L.L., Nghia, T.T., \& Hanh, T.T.H. (2007). Development of nursery culture techniques for the mud cran Scylla paramamosain (Estampador). Aquaculture Research, 38, 1563-1568.

Wilson, E.O. (1975). Aggression; sociobiology: the new synthesis. Harvard University Press. Cambaridge, p. 242-255.

Wilson, R.P. (2002). Animo acid and protein. In Halver, J.E., \& Hardy, R.W. (Eds.). Fish Nutrition. Academic Press. New York, p. 143-179.

Winberg, S., \& Nilsson, G.E. (1993). Roles of brain monoamine neurotransmitters in agonistic behaviour and stress reactions, with particular reference to fish. Comp. Biochem. Physiol., C. 106, 597-614.

Young, S.N. (1996). Behavioral effects of dietary neurotransmitter precursor, basic and clinical aspects. Neurosci. Biobehav. Rev., 20, 313-323. 